\title{
Correction to: Some strengthened versions of Klamkin's inequality and applications
}

\section{Quang Hung $\operatorname{Tran}^{1}$ (D)}

Published online: 9 February 2021

(c) Springer Nature B.V. 2021

\section{Correction to: Geometriae Dedicata} https://doi.org/10.1007/s10711-020-00591-x

In the first page of the published article, the author name is mistakenly spelled out as Klamlein. The correct version of the author name is given below,

"Dedicated to the memory of Professor Murray Seymour Klamlein (1921-2004)".

"The original article has been corrected".

Publisher's Note Springer Nature remains neutral with regard to jurisdictional claims in published maps and institutional affiliations.

The original article can be found online at https://doi.org/10.1007/s10711-020-00591-X.

Quang Hung Tran

tranquanghung@hus.edu.vn

1 High School for Gifted Students, Hanoi University of Science, Vietnam National University at Hanoi, 182 Luong The Vinh, Thanh Xuan, Hanoi, Vietnam 